Advances in Natural Sciences:

Nanoscience and Nanotechnology

\title{
PAPER
}

\section{In situ growth of CuO nanoparticles onto cotton textiles}

To cite this article: Luz E Román et al 2020 Adv. Nat. Sci: Nanosci. Nanotechnol. 11025009

View the article online for updates and enhancements. 


\title{
In situ growth of CuO nanoparticles onto cotton textiles
}

\author{
Luz E Román ${ }^{1}$, Manuel J Amézquita ${ }^{2}$, Carmen L Uribe ${ }^{2}$, Dora J Maurtua ${ }^{3}$, \\ Silgia A Costa ${ }^{4}$, Sirlene M Costa ${ }^{4}$, Riitta Keiski ${ }^{5}$, José L Solís ${ }^{1}$ and \\ Mónica M Gómez ${ }^{1}$
}

\author{
${ }^{1}$ Faculty of Science, Universidad Nacional de Ingeniería, Av. Túpac Amaru 210, Lima 25, Peru \\ ${ }^{2}$ Faculty of Chemical and Textile Engineering, Universidad Nacional de Ingeniería, Av. Túpac Amaru 210, \\ Lima 25, Peru \\ ${ }^{3}$ Faculty of Science and Philosophy, Universidad Peruana Cayetano Heredia, Av. Honorio Delgado 430, \\ Lima 25, Peru \\ ${ }^{4}$ Course on Textiles and Fashion, School of Arts, Sciences and Humanities, University of São Paulo, \\ Arlindo Bettio Av. 1000, São Paulo, Brazil \\ ${ }^{5}$ Faculty of Technology, Environmental and Chemical Engineering, University of Oulu, PO Box 4300, \\ FI-90014 University of Oulu, Finland
}

E-mail:mgomez@uni.edu.pe

Received 26 December 2019

Accepted for publication 19 February 2020

Published 5 May 2020

\begin{abstract}
The application of nanotechnology has gained importance in the finishing of textile products, imparting them functional properties, which are achieved without affecting the textile. A novel method was developed for the in situ growth of $\mathrm{CuO}$ nanoparticles (NPs) onto cotton textiles by the exhaust dyeing method. For functionalised textiles, a constant sodium hydroxide concentration $\left(0.4 \mathrm{~g} \mathrm{l}^{-1}\right)$ and different percentages of on-weight-fabric (\% owf) of copper acetate were used. The textiles were microbiologically evaluated, the laundering durability was assessed and their UV protection factor (UPF) was determined. In addition, their CIE $L * a * b *$ colour coordinates and colour strength $(K / S)$ were studied. The results determined that NPs on the textile were $\mathrm{CuO}$ and were distributed randomly on the cotton fibre surface. The functionalised textiles with $\mathrm{CuO}$ NPs had percentages of bacterial reduction against Escherichia coli (ATCC 25922) between 89.7 and $99.7 \%$ and showed an improvement in the UPF of cotton from approximately 7 to 32 . The $\mathrm{CuO}$ NP content on the textile was inversely correlated with the L* value and directly correlated with the $\mathrm{a} *$ and $\mathrm{b} *$ values and the $K / S$ parameter.
\end{abstract}

Keywords: In situ, $\mathrm{CuO}$ nanoparticles, textile functionalization, antimicrobial, UPF

\section{Introduction}

Nanotechnology is a promising 21 st century tool because of its contributions to different research areas such as medicine, physics, chemistry, biotechnology, electronics, telecommunications, and agriculture [1-3], where it acts as a synergetic nexus among these fields $[4,5]$. For the industrial sector, technologies drive the competitive advantage because they improve the performance and innovation of an industry. In this sense, nanotechnology may be the most important investment that a firm makes to increase its innovative performance [4]. Over the past decades, the textile industry has been innovating and improving its products and processes through the application of nanotechnology [6]; thereby, nanotechnology has gained importance in the processing and finishing of textile products, imparting them enhanced and/or novel properties, which can be achieved without affecting the fabric's texture and breathability [7]. Various nanoparticle structures have been immobilised onto textiles to provide them with new properties [8-10]. This immobilisation can be obtained by ex situ and in situ methods. Ex situ methods consist of synthesising the NPs and then applying them onto fabric surface, while for in situ methods, NPs grow in the presence of the fabric [11, 12]. Antimicrobial textiles can be functionalised by means of both methods using metal and metal oxide nanoparticles (NPs), like $\mathrm{Ag}, \mathrm{Si}, \mathrm{Cu}, \mathrm{Au}$, silver 


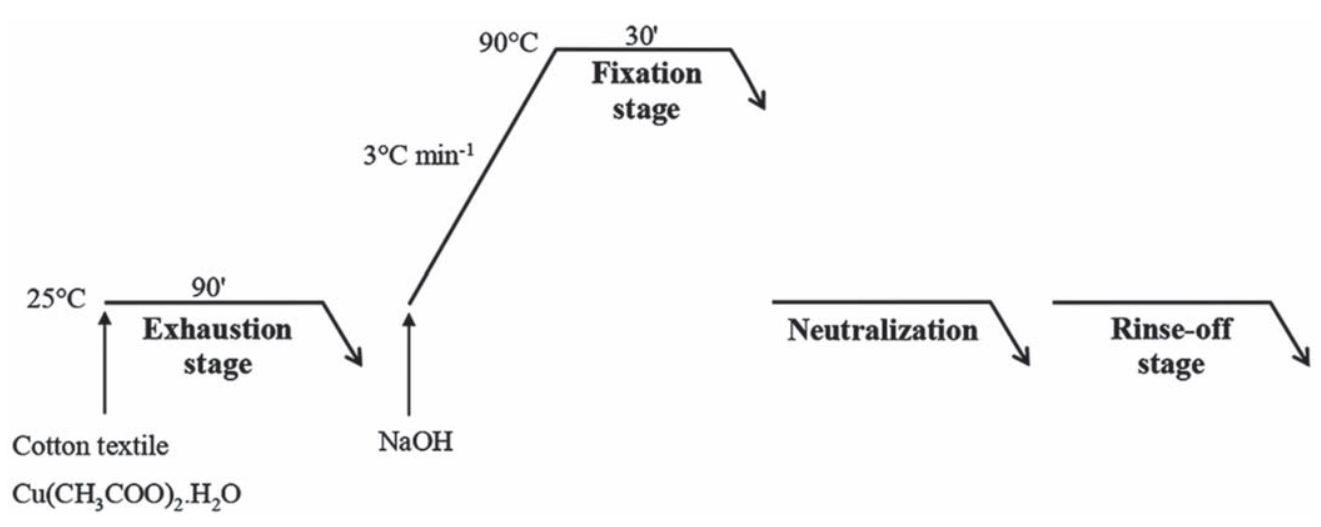

Figure 1. Functionalisation curve of cotton textiles with $\mathrm{CuO}$ NPs prepared from $\mathrm{Cu}\left(\mathrm{CH}_{3} \mathrm{COO}\right)_{2} \cdot \mathrm{H}_{2} \mathrm{O}$ and $\mathrm{NaOH}$ by the exhaust dyeing method.

oxide $\left(\mathrm{Ag}_{2} \mathrm{O}\right)$, titanium dioxide $\left(\mathrm{TiO}_{2}\right)$, zinc oxide $(\mathrm{ZnO})$ and copper oxide $(\mathrm{CuO})$ [13-15]. Specifically, $\mathrm{CuO}$ is a p-type semiconductor with a band gap of approximately $1.2 \mathrm{eV}$, where copper has an oxidation number of +2 and has distinctive physico-chemical properties, such as low solubility and high-temperature superconductivity [16-18]. Additionally, $\mathrm{CuO}$ does not cause skin irritation, sensitisation or adverse reactions [19]. However, the most important property, which is the topic of the present work, is that $\mathrm{CuO}$ has antifungal and antibacterial activity for gram-positive and gramnegative bacteria [20-22]. Moreover, $\mathrm{CuO}$ nanoparticles, as antimicrobial agents, are more stable and durable than organic antimicrobial compounds [23].

Application or functionalisation of textile with antimicrobial agents based on $\mathrm{CuO}$ NPs can be carried out by different methods, e.g., El-Nahhal et al (2018) reported a functionalisation process for cotton fibres with $\mathrm{CuO}$ NPs using copper sulfate pentahydrate $(1.25 \mathrm{~g}, 0.005 \mathrm{~mol})$ with sodium hydroxide $(0.4 \mathrm{~g}, 0.01 \mathrm{~mol})$ by a sonication method. They achieved excellent inhibition of bacterial growth and found that the use of surfactants stabilised the cotton/CuONP system. Rezaie et al (2017) obtained polyester fabrics with UV protection properties and excellent antibacterial activities after 5 washes. They used Keliab from Seidlitzia rosmarinus as a natural alkaline source for the green reduction of a copper acetate solution $(0.2 \mathrm{M})$ in the presence of polyester to obtain $\mathrm{CuO}$ NPs [24]. Gouda et al (2015) developed cotton fabrics with multifunctional properties, such as antibacterial, UV protection and flame retardant, by the in situ synthesis of metal NPs using microwave irradiation [25]. In the research conducted by Thampi et al (2015), $\mathrm{CuO}$ NPs were synthesised by employing the chemical precipitation method, and then they were immobilised on the surface of cotton fabric by immersion. The treated fabrics showed a clear zone of inhibition against gram-positive and gramnegative bacteria [26].

The above mentioned studies reported good antimicrobial results but required the use of unusual methods and instruments from the textile wet-processing industry. In this sense, to contribute to textile innovation, the current research describes the development process for the in situ growth of $\mathrm{CuO}$ NPs onto textile materials, employing the conventional dyeing method (exhaust dyeing method) and high-temperature equipment present in all textile laboratories to provide antimicrobial properties in simple cotton fabrics. Therefore, this proposed innovation presents an economic, simple and highly effective approach for obtaining functional textile materials. In this paper, the quality control for textiles was studied and determined such as the colour coordinates, colour strength $(\mathrm{K} / \mathrm{S})$, antimicrobial activity (according to the American Society for Testing and Materials, ASTM, E214901 standard), ultraviolet protection (using the American Association of Textile Chemist and Colorists, AATCC, 183-2014 standard) and laundering durability test (in agreement with the International Organization for Standardization (ISO) 105-C06:1994 standard). Additionally, structural, morphological and thermogravimetric characterisations of in situ functionalised cotton textiles with $\mathrm{CuO}$ NPs were performed and studied.

\section{Materials and methods}

\subsection{Materials}

All chemical reagents used in this research were of chemically pure grade. Between different copper salts, copper acetate monohydrate $\left(\mathrm{Cu}\left(\mathrm{CH}_{3} \mathrm{COO}\right)_{2} \cdot \mathrm{H}_{2} \mathrm{O}\right)$ was chosen due to its water-soluble secondary products, a condition that helps to eliminate them easily during the rinsing of the textiles in the functionalisation process. Copper acetate monohydrate $\left(\mathrm{Cu}\left(\mathrm{CH}_{3} \mathrm{COO}\right)_{2} \cdot \mathrm{H}_{2} \mathrm{O}\right)$ and sodium hydroxide $(\mathrm{NaOH})$ were obtained from Merck Millipore. The material used to obtain the antimicrobial textile was $100 \%$ cotton fabric and was supplied by Tejidos San Jacinto S.A., Peru.

\subsection{In situ synthesis of CuO NPs on cotton textiles}

The cotton textiles were in situ functionalised with $\mathrm{CuO}$ nanoparticles using the exhaust dyeing method, employing a Mathis ALT-ECO high-temperature machine. The functionalisation process was separated into four stages, as shown in figure 1. (1) Exhaustion stage: the $\mathrm{Cu}^{2+}$ is moved from the exhaustion bath to the cotton textiles due to the decomposition of the copper acetate salt in aqueous media into copper 
ions $\left(\mathrm{Cu}^{2+}\right)$ and acetate ions $\left(\mathrm{CH}_{3} \mathrm{COO}^{-}\right)$[27, 28]. (2) Fixation stage: a chemical reaction occurs between $\mathrm{Cu}^{2+}$ ions and hydroxide ions $\left(\mathrm{OH}^{-}\right)$resulting from the complete ionisation of $\mathrm{NaOH}$ in water. Copper hydroxide $\left(\mathrm{Cu}(\mathrm{OH})_{2}\right)$ is formed first and is then transformed to stable $\mathrm{CuO}$ through $\mathrm{Cu}(\mathrm{OH})_{4}^{2-}$, which is an intermediate species in the chemical reaction $[23,29,30]$. (3) Neutralisation stage: in this stage, glacial acetic acid $\left(\mathrm{CH}_{3} \mathrm{COOH}\right)$ is used to neutralise the cotton textile. (4) Rinse-off stage: the functionalised textiles are washed with distilled water to remove residues of acetic acid and $\mathrm{CuO}$ NPs that were not attached to the textile.

\subsection{Functionalisation process}

In a dyeing process, the amount of chemical finish or dye applied on textile materials is usually expressed as a weight percentage based on the original fabric weight. This expression is often represented as percent on-weight-fabric (\% owf) [31]. For the functionalisation process, the cotton textile was cut into $5.0 \mathrm{~g}$ pieces and then added to stainless-steel beakers containing $50 \mathrm{ml}$ of $\mathrm{Cu}\left(\mathrm{CH}_{3} \mathrm{COO}\right)_{2} \cdot \mathrm{H}_{2} \mathrm{O}$ aqueous solutions. Concentrations of $0.2,0.4,0.6,0.8,1.0,1.2$ and $30.0 \%$ owf were prepared. The liquor ratio used was 10:1 (bath volume $(\mathrm{mL})$ : textile weight $(g)$ ) [32]. The stainless-steel beakers were covered and introduced into the textile machine for high-temperature exhaust dyeing; the beakers were kept under rotation at $40 \mathrm{rpm}$ for $90 \mathrm{~min}$ at room temperature (exhaustion stage). At the end of the exhaustion time, the $\mathrm{Cu}\left(\mathrm{CH}_{3} \mathrm{COO}\right)_{2} \cdot \mathrm{H}_{2} \mathrm{O}$ solution was discarded. Afterwards, $50 \mathrm{ml}$ of a $0.4 \mathrm{~g} \mathrm{l}^{-1} \mathrm{NaOH}$ solution was added to the textile samples, and the stainless-steel beakers were again kept under continuous rotation at $40 \mathrm{rpm}$ for $30 \mathrm{~min}$ at $90{ }^{\circ} \mathrm{C}$ (fixation stage). Finally, the samples were neutralised with $0.5 \mathrm{~g} \mathrm{l}^{-1}$ $\mathrm{CH}_{3} \mathrm{COOH}$, washed three times with distilled water and dried at $70{ }^{\circ} \mathrm{C}$ (neutralisation and rinse-off stages).

\subsection{Colourimetric analysis}

The colourimetric properties of nonfunctionalised and in situ functionalised cotton textiles with $\mathrm{CuO}$ NPs were obtained using a Datacolor 550 TM spectrophotometer. The calibration conditions considered the specular component, UV filter and small aperture size with a measured sample area of $5 \mathrm{~mm}$ and an illuminated sample area of $9 \mathrm{~mm}$. The CIELAB colour space coordinates of $L *$ (lightness), $a *$ (redness-greenness) and $b *$ (blueness-yellowness) and the colour strength $(\mathrm{K} / \mathrm{S})$ of $\lambda_{\max }$ were determined by Datacolor Tools software. All measurements were carried out with the standard illuminant D65 and at a $10^{\circ}$ observing angle; furthermore, each textile sample was measured in triplicate.

\subsection{Microbiological analysis test}

The microbiological analysis of nonfunctionalised and in situ functionalised cotton textiles with $\mathrm{CuO}$ NPs was performed according to the ASTM E2149-01 standard testing method for determining the antimicrobial activity of immobilised antimicrobial agents under dynamic contact conditions.
Escherichia coli (ATCC 25922), a gram-negative bacterium, was used in this analysis. The procedure was as follows: the Escherichia coli strain was grown in sterile tryptic soy broth (TSB) for $18 \mathrm{~h}$ at $37^{\circ} \mathrm{C}$ and then was centrifuged at $4000 \mathrm{rpm}$ for $10 \mathrm{~min}$ The bacteria obtained were diluted with a sterile

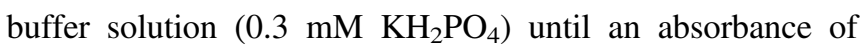
$0.28 \pm 0.02$ at $475 \mathrm{~nm}$ was achieved, which is equivalent to $1.5-3.0 \times 10^{8}$ colony-forming units (CFU) per millilitre. The bacterial suspension concentration was measured using a Genesys 20 (4001/4) visible spectrophotometer (Thermo Electron Corporation). This bacterial suspension was diluted again into a buffer solution to obtain a final concentration of

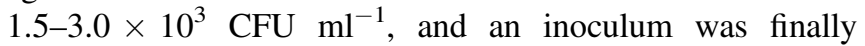
placed on the surface of a sterile Petri dish containing tryptic soy agar (TSA). Afterwards, a $0.5 \mathrm{~g}$ piece of sterile textile was cut into small pieces and placed inside an Erlenmeyer flask containing $50 \mathrm{ml}$ of buffer solution with $1.5-3.0 \times 10^{3}$ $\mathrm{CFU} \mathrm{ml}{ }^{-1}$ Escherichia coli. The flasks were incubated at $37{ }^{\circ} \mathrm{C}$ and continuously shaken at low revolution for $1 \mathrm{~min}$ and then at maximum revolution for $1 \mathrm{~h}$. After incubation, the buffer solution, which was in contact with the cotton samples, was diluted, and fractions were plated on a Petri dish with TSA ( $1 \mathrm{~h}$ contact time). All the Petri dishes were incubated at $37^{\circ} \mathrm{C}$ for $24 \mathrm{~h}$, and the $\mathrm{CFU} \mathrm{ml}{ }^{-1}$ was calculated by multiplying the number of colonies by the dilution factor. The nonfunctionalised cotton textile was used as a control. All analyses were conducted in duplicate under the same conditions. The antibacterial activity is expressed in terms of the percent reduction of the bacteria after contact with the functionalised textile compared to the number of bacterial cells surviving after contact with the nonfunctionalised textile. The results are reported as a percent bacterial reduction and are calculated using equation 1 :

$$
\text { Reduction, } \%(\mathrm{CFU} / \mathrm{mL})=\frac{C-A}{C} \times 100 \% \text {, }
$$

where $C$ and $A$ are the numbers of bacteria colonies recovered from the nonfunctionalised and functionalised textiles, respectively, after the $1 \mathrm{~h}$ contact time.

\subsection{UV-protection factor (UPF) measurement}

The AATCC 183-2014 standard was used with modifications to evaluate the UPF of the nonfunctionalised and in situ functionalised cotton textiles with $\mathrm{CuO}$ NPs. The UPF measurements were performed in the range of 280-400 nm using a Spectronic UV-visible spectrophotometer, model CamSpecM550. The assessment process consisted of exposing a $5 \mathrm{~cm} \times 5 \mathrm{~cm}$ textile sample to UV radiation and measuring the transmission every $45^{\circ}$ of rotation through the textile. Six measurements were made, and the UPF was calculated using equation 2 [33]:

$$
\mathrm{UPF}=\frac{\sum_{280 \mathrm{~nm}}^{400 \mathrm{~nm}} E_{\lambda} S_{\lambda} \Delta \lambda}{\sum_{280 \mathrm{~nm}}^{400 \mathrm{~nm}} E_{\lambda} S_{\lambda} T_{\lambda} \Delta \lambda},
$$

where $E_{\lambda}$ is the relative erythemal spectral effectiveness, $S_{\lambda}$ is the solar spectral irradiance, $T_{\lambda}$ is the average spectral 
(a)

(b)

(c)

(d)

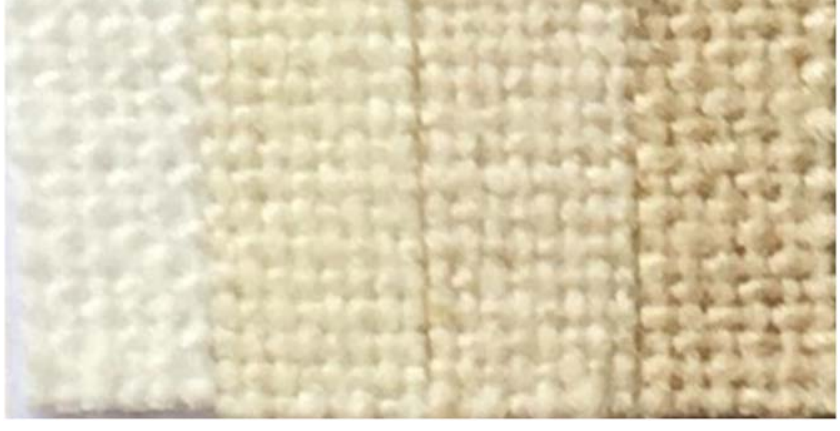

Figure 2. Cotton textile samples: (a) nonfunctionalised and in situ functionalised with $\mathrm{CuO}$ NPs using (b) $0.2 \%$, (c) $1.2 \%$ and (c) $30 \%$ owf $\mathrm{Cu}\left(\mathrm{CH}_{3} \mathrm{COO}\right)_{2} \cdot \mathrm{H}_{2} \mathrm{O}$.

transmittance of the specimen and $\Delta \lambda$ is the measured wavelength interval $(\mathrm{nm})$.

According to the Australian/New Zealand (AS/NZS) 4399:1996 standard, the UPF of textile fabrics can be classified into three protection categories: good protection (UPF: 15-24), very good protection (UPF: 25-39) and excellent protection (UPF: $40-50,50+$ ) [34].

\subsection{Characterisation of cotton textile}

$\mathrm{x}$-ray diffraction (XRD) analysis of the nonfunctionalised and in situ functionalised cotton textiles with $\mathrm{CuO}$ NPs was performed employing a Siemens D5000 diffractometer with a $\mathrm{Cu}-\mathrm{K} \alpha$ radiation source of wavelength $\lambda=1.54 \AA$. The diffraction angle ranged from $30^{\circ}$ to $40^{\circ}$. The surface morphology of the same textiles was assessed via fieldemission scanning electron microscopy (FESEM) using a Zeiss Ultra Plus instrument and a Hitachi SU8230. In addition, thermogravimetric analysis (TGA) was performed using a Setaram LABSYS Evo system, and the cotton textiles were tested under an atmospheric air flow at temperatures from 30 to $900{ }^{\circ} \mathrm{C}$.

\subsection{Laundering durability test}

The ISO test method 105-C06:1994 with procedure $\mathrm{N}^{\circ} \mathrm{B} 1 \mathrm{M}$ using light modifications was used to evaluate the laundering durability of functionalised cotton textile [35]. Textile samples were laundered in a $500 \mathrm{ml}$ stainless steel beaker containing 50 stainless steel balls and $150 \mathrm{ml}$ wash solution. This solution was initially prepared with $4 \mathrm{~g}$ of a standard reference detergent without optical brightener in 11 of distilled water. The beakers were placed inside the laundering machine (Launder-Ometer, Atlas Electric Devices Co) preheated at $50{ }^{\circ} \mathrm{C}$ and kept at a constant rotation of $40 \mathrm{rpm}$ for $45 \mathrm{~min}$. At the end of the laundering process, the textile samples were rinsed-off with distilled water for $10 \mathrm{~s}$ and dried at $60{ }^{\circ} \mathrm{C}$.

\section{Results and discussion}

The exhaust dyeing method was used for the in situ growth of $\mathrm{CuO}$ NPs on cotton textiles. Figure 2 shows the images of nonfunctionalised and in situ functionalised cotton textiles with $\mathrm{CuO}$ NPs using $0.2 \%, 1.2 \%$ and $30.0 \%$ owf $\mathrm{Cu}\left(\mathrm{CH}_{3} \mathrm{COO}\right)_{2} \cdot \mathrm{H}_{2} \mathrm{O}$. A visual assessment of colour showed that the functionalised textiles acquired a grayish-brown shade of low chromaticity, which varies in lightness. In this sense, as the percentage of $\mathrm{Cu}\left(\mathrm{CH}_{3} \mathrm{COO}\right)_{2} \cdot \mathrm{H}_{2} \mathrm{O}$ increased in the exhaustion stage, the grayish-brown colour of the textile became more intense and darker. This visual variation in colour shows the presence and increase in $\mathrm{CuO}$ NPs on the textile [36].

The CIE $L * a * b *$ colour coordinates and colour strength $(\mathrm{K} / \mathrm{S})$ values were determined from the spectrophotometric readings to verify the colour variation in textile samples with regard to the concentration of the copper acetate solution. The value of $L *$ is a measure of the lightness of the colour and varies between 0 (perfectly black) and 100 (perfectly white) [37]. According to figure 3(a), the lightness $(L *)$ of the textile samples decreased as the concentration of copper acetate increased, which indicates that the textile samples became darker due to the higher $\mathrm{CuO} \mathrm{NP}$ content on the surface of the textile. On the other hand, the red-green measurement of a specific sample is attributed to the value of $a *$, where the positive and negative values are for the red and green shades, respectively [37]. The value of $b *$ gives the yellow-blue character of the textile: when the values of $b *$ are positive, the shades are yellow; when the values are negative, the shades are blue [37]. For our case, the rednessgreenness value $(a *)$ of the nonfunctionalised textile was 0.15 , which changed to higher and positive values for all functionalised textiles; that is, the textiles became more reddish, as shown in figure 3(b). Figure 3(c) reports the values of yellowness-blueness $(b *)$; nonfunctionalised textile presented a value of 4.88 , which was modified to values of 10.31 to 13.63 after functionalisation. Therefore, the CIE $L * a * b *$ values indicate that the colour of the textile samples acquired a more yellow colour and nearly constant shade during the functionalisation process. In addition, the $K / S$ parameters for the textiles were determined and are represented in figure 3(d). In this figure, the $K / S$ values have a linear growth trend with respect to the increase in $\mathrm{Cu}\left(\mathrm{CH}_{3} \mathrm{COO}\right)_{2} \cdot \mathrm{H}_{2} \mathrm{O}$ from $0.2 \%$ to $30 \%$ owf in the exhaustion stage. This linear behaviour fits the Kubelka-Munk equation, which relates the absorption and scattering coefficients and the concentrations of the dye [37]; the $\mathrm{K} / \mathrm{S}$ parameter is a quantitative measure that is directly correlated with the dye concentration on the substrate [38]. Thus, the equation indicates that at high values of $\mathrm{K} / \mathrm{S}$, the concentration of $\mathrm{CuO} \mathrm{NPs}$ in the textile is also high. Finally, these results corroborate and complement the information shown and discussed above in figures 2 and 3(a).

The antimicrobial activity of nonfunctionalised and in situ functionalised cotton textiles with $\mathrm{CuO}$ NPs using 0.2 , $0.4,0.6,0.8,1.0,1.2$ and $30.0 \%$ owf $\mathrm{Cu}\left(\mathrm{CH}_{3} \mathrm{COO}\right)_{2} \cdot \mathrm{H}_{2} \mathrm{O}$ against Escherichia coli is shown in figure 4, which displays 


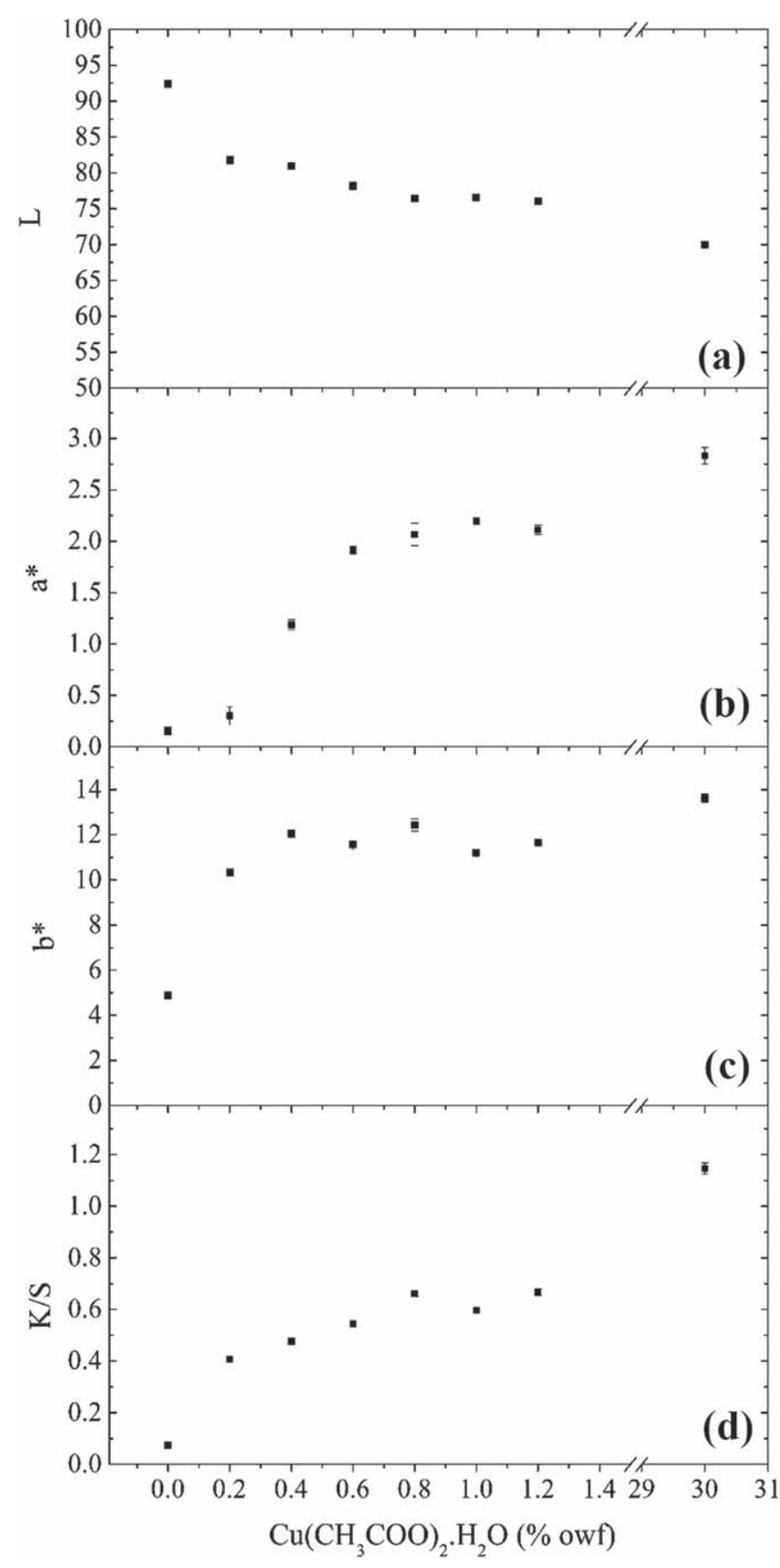

Figure 3. Colourimetric analysis of nonfunctionalised and in situ functionalised cotton textiles with CuO NPs. (a) $L$ (lightness), (b) $a *$ (red-green axis), (c) $b *$ (yellow-blue axis) and (d) colour strength $(K / S)$.

the bacterial colony count in Petri dishes. Figure 4(a) displays the number of bacterial cells surviving after contact with the nonfunctionalised textile and, figures 4(b)-(h) present the numbers of bacteria colonies recovered after contact with the functionalised textile ( $1 \mathrm{~h}$ contact time).

Figure 5 displays the percent reduction against Escherichia coli bacteria of nonfunctionalised and in situ functionalised cotton textiles with $\mathrm{CuO}$ NPs prepared using 0.2, 0.4, $0.6,0.8,1.0,1.2$ and $30 \%$ owf $\mathrm{Cu}\left(\mathrm{CH}_{3} \mathrm{COO}\right)_{2} . \mathrm{H}_{2} \mathrm{O}$ according to the ASTM E2149-01 standard. As the percentage of copper acetate increased from 0.0 to $0.6 \%$, the percent reduction of the bacteria $(\mathrm{R} \%)$ also increased, reaching a maximum value of $99.4 \%$. For the following copper acetate percentages, except for one case $(0.8 \%)$ which presented a slight decrease in reduction of the bacterial load, the $\mathrm{R} \%$ remained relatively constant, achieving an average of $98.6 \%$. This antimicrobial activity of the functionalised textiles is due to the presence of $\mathrm{CuO}$ NPs; that is, the property of inhibiting bacterial growth was conferred to the textile upon in situ incorporation of $\mathrm{CuO}$ NPs, and this behaviour is related to the broad antimicrobial activity of $\mathrm{CuO}$ against gram-positive and gram-negative bacteria [21, 39]. According to the study of Rezaie et al (2018), the functionalised cotton fabrics with $\mathrm{CuO}$ NPs show good antibacterial performance (100\% bacterial reduction) against Staphylococcus aureus (S. aureus) (gram-positive) and Escherichia coli (E. coli) (gram-negative) [36]. A similar result was reported by El-Nahhal et al (2018); in their study, it was found that $\mathrm{CuO}$ NP-coated cotton fabrics had percentages of bacterial reduction of more than $90 \%$ against E. coli and $S$. aureus strains. Similarly, Thampi et al (2015) reported the growth inhibition of E. coli and S. aureus when they studied the bacterial behaviour of a cotton fabric sample impregnated with $\mathrm{CuO}$ NPs and with polyaniline (PANI)/CuO. The results of the present study match the results reported in the references [8], [26] and [36], which were described above. This similarity may be related to the mechanism of the antimicrobial behaviour of $\mathrm{CuO}$ NPs in textiles. The mechanism consists of the diffusion of water molecules coming from the bacteria medium through cotton cellulose; the dissolved oxygen in water causes the corrosion or dissolution of nanoparticles present in the textile, resulting in the release of copper ions [36, 40]. When the copper ions contact bacteria, they can damage the cell membrane by producing reactive hydroxyl radicals and by oxidising lipids and proteins; afterwards, these ions can diffuse into the bacterial cells and cause their death [36, 40, 41]. In addition to the mechanism described and according to Tamayo et al (2016), a large amount of reactive oxygen species (ROS) is produced on surface defect sites in nanocrystalline $\mathrm{CuO}$ [42]. This production of ROS on the $\mathrm{CuO}$ surface and the adherence of the same particle to a bacterial cell membrane cause an increase in cell permeability, resulting in the transport of $\mathrm{CuO}$ through the cytoplasmic membrane and, as a consequence, causing bacterial cell death $[21,42,43]$. Therefore, and in accordance with the existing literature, the increase in microbiological activity of cotton textiles as the CuO NPs content increased may be due to the formation of more ROS and an increase in copper ion release, thus causing greater bacterial cell death.

The UPF of a fabric is influenced by different characteristics, such as porosity, weight, thickness, type of fabric, fabric structure, laundering method, and colour [44]. In addition, the dye concentration and $L *$ value of the colour coordinates of the CIE $L * a * b *$ system have a direct and inverse relationship with the UPF values, respectively [45]. The higher the dye concentration, the higher the UPF value and vice versa; the higher the lightness of the fabric, the lower the UPF. Thus, a coloured fabric has better UV protection than a white fabric because a larger amount of UV radiation is absorbed by darker colours than by lighter colours, thus 

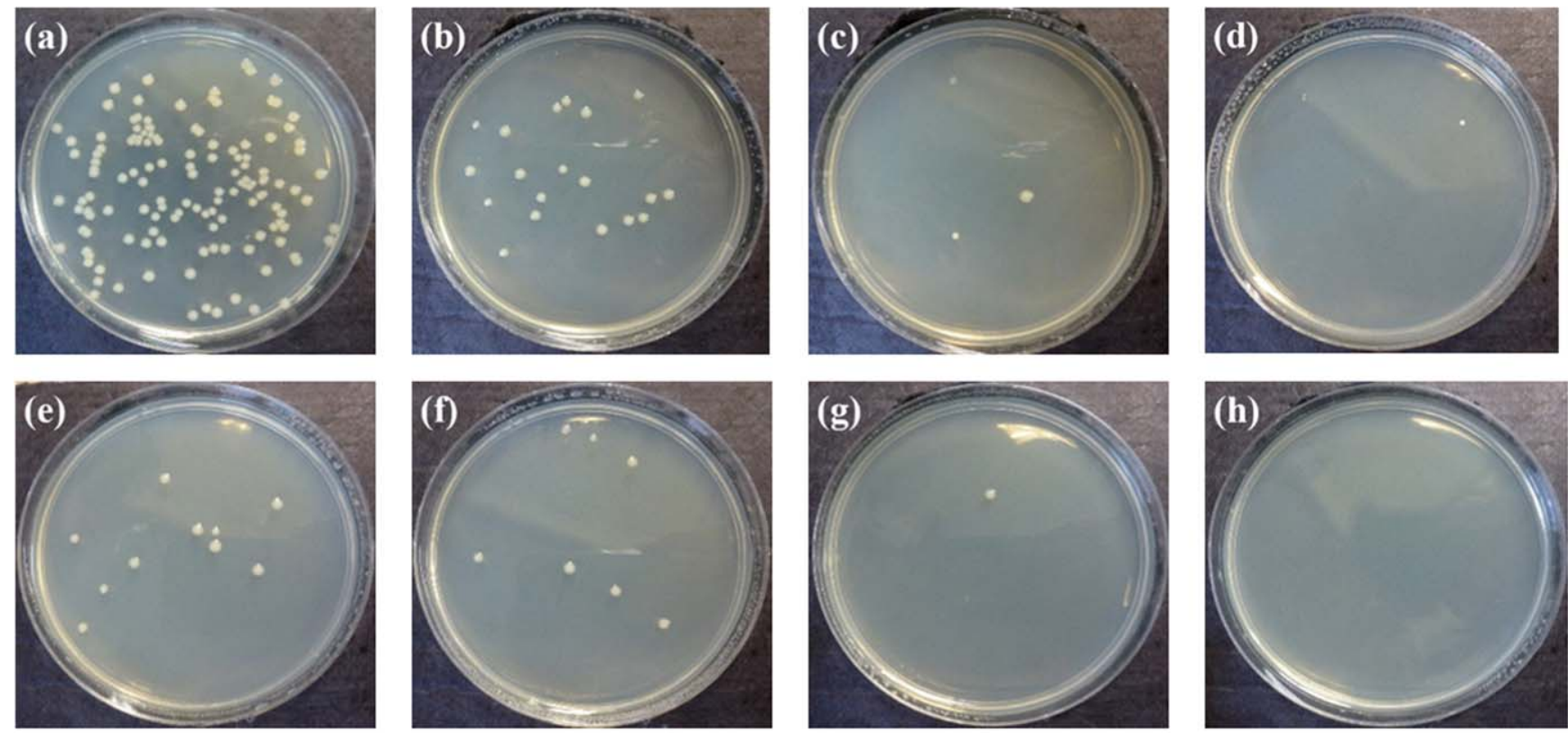

Figure 4. Bacterial count of Escherichia coli strain after $1 \mathrm{~h}$ contact time: (a) nonfunctionalised and in situ functionalised with CuO NPs using (b) $0.2 \%$, (c) $0.4 \%$, (d) $0.6 \%$, (e) $0.8 \%$, (f) $1.0 \%$, (g) $1.2 \%$ and (h) $30 \%$ owf $\mathrm{Cu}\left(\mathrm{CH}_{3} \mathrm{COO}\right)_{2} . \mathrm{H}_{2} \mathrm{O}$.

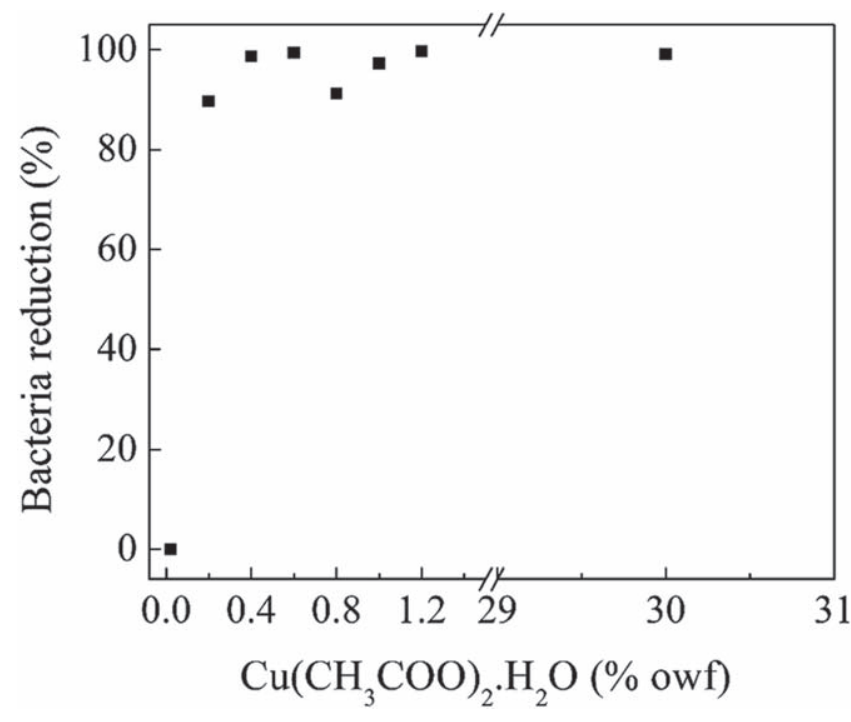

Figure 5. Percent reduction against Escherichia coli bacteria of nonfunctionalised and in situ functionalised cotton textiles with $\mathrm{CuO}$ NPs prepared using 0.2, 0.4, 0.6, 0.8, 1.0, 1.2 and $30 \%$ owf $\mathrm{Cu}$ $\left(\mathrm{CH}_{3} \mathrm{COO}\right)_{2} \cdot \mathrm{H}_{2} \mathrm{O}$ according to the ASTM E2149-01 standard.

providing good UV protection [44, 46]. For example, as shown in figure 6, the in situ functionalised cotton textiles with $\mathrm{CuO}$ NPs prepared using 0.2, 0.4, 0.6, 0.8, 1.0, 1.2 and $30.0 \%$ owf $\mathrm{Cu}\left(\mathrm{CH}_{3} \mathrm{COO}\right)_{2} \cdot \mathrm{H}_{2} \mathrm{O}$ acquired a grayish-brown shade and had increased UPF values, reaching between 20.2 and 32.4, which are three to five times higher than those of the nonfunctionalised white fabric (UPF $=7.2$ ) (figure 2). Additionally, figure 6 shows that when the copper acetate concentration in the exhaustion bath increased from $0.2 \%$ to $30 \%$ owf, the value of the colour coordinate $L *$ decreased from 92.4 to 70.0, and there was an increase in the UPF values of the textiles. This improvement in UV protection

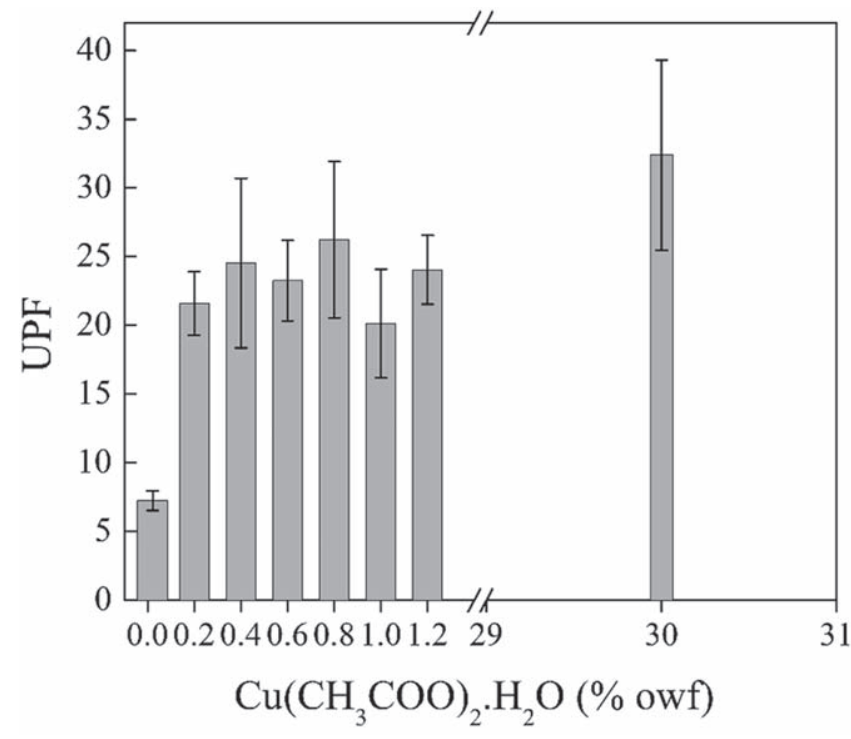

Figure 6. UPF values of nonfunctionalised and in situ functionalised cotton textiles with $\mathrm{CuO}$ NPs prepared using 0.2, 0.4, 0.6, 0.8, 1.0, 1.2 and $30 \%$ owf $\mathrm{Cu}\left(\mathrm{CH}_{3} \mathrm{COO}\right)_{2} \cdot \mathrm{H}_{2} \mathrm{O}$.

may be due to the grayish-brown shade of the textile given by the $\mathrm{CuO}$ and the presence of $\mathrm{CuO}$ NPs, which can absorb and block the transmission of ultraviolet radiation through the textile, thus improving the UV protection [36, 45]. Finally, according to the AS/NZS 4399:1996 standard and the results obtained, the functionalised cotton textiles could be categorised as providing good to very good UV protection.

The $\mathrm{CuO}$ produced by chemical reactions between $0.2,0.4$, $0.6,0.8,1.0$ and $1.2 \%$ owf $\mathrm{Cu}\left(\mathrm{CH}_{3} \mathrm{COO}\right)_{2} \cdot \mathrm{H}_{2} \mathrm{O}$ and $0.4 \mathrm{~g} \mathrm{l}^{-1}$ $\mathrm{NaOH}$ is in very small quantities on the cotton textile and was undetectable by XRD and FESEM. For those reasons, the functionalised textile with $30 \%$ owf $\mathrm{Cu}\left(\mathrm{CH}_{3} \mathrm{COO}\right)_{2} \cdot \mathrm{H}_{2} \mathrm{O}$ is 


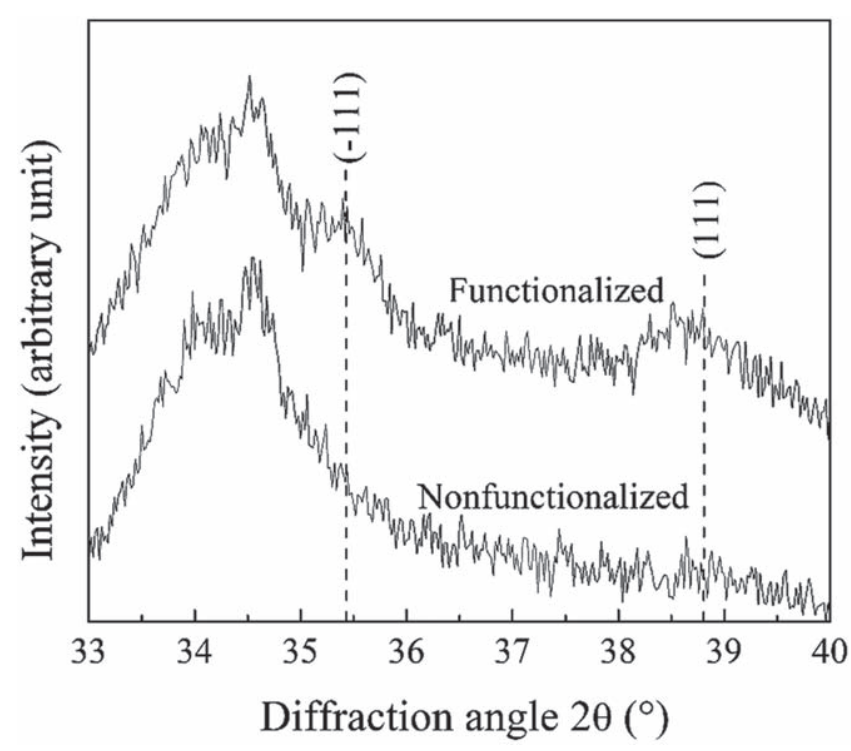

Figure 7. XRD patterns of nonfunctionalised and in situ functionalised cotton textiles with $\mathrm{CuO}$ NPs prepared using $30 \%$ owf $\mathrm{Cu}$ $\left(\mathrm{CH}_{3} \mathrm{COO}\right)_{2} \cdot \mathrm{H}_{2} \mathrm{O}$.

taken as a reference sample in the following analyses. To confirm the presence of $\mathrm{CuO}$ NPs on the cotton textile, XRD was performed. Figure 7 shows the XRD patterns of nonfunctionalised and in situ functionalised cotton textiles using $30.0 \%$ owf $\mathrm{Cu}\left(\mathrm{CH}_{3} \mathrm{COO}\right)_{2} \cdot \mathrm{H}_{2} \mathrm{O}$. Compared to the nonfunctionalised textile, the functionalised cotton textile has two distinct diffraction peaks at $2 \theta$ values of approximately $35.5^{\circ}$ and $38.8^{\circ}$ corresponding to $(-111)$ and (111) Miller indices, which belong to the crystalline planes of $\mathrm{CuO}[41,47]$. Based on these results, the particles synthesised in situ on the cotton textiles are $\mathrm{CuO}$.

Thermogravimetric analysis of nonfunctionalised and in situ functionalised cotton textiles using $30.0 \%$ owf $\mathrm{Cu}\left(\mathrm{CH}_{3} \mathrm{COO}\right)_{2} \cdot \mathrm{H}_{2} \mathrm{O}$ was performed with the aim of obtaining information on the thermal behaviour of the textiles and the percentage of nanoparticles present on the cotton after the functionalisation process. Figure 8 shows that in the TGA curves, there are two steps of thermal degradation. In the first step, a weight loss is observed between the temperatures of 50 and $200{ }^{\circ} \mathrm{C}$, associated with the evaporation of water molecules in cotton fibres [48]. The second step, which is the most important, occurs in the range of $200-400{ }^{\circ} \mathrm{C}$ and is attributed to the thermal degradation of cellulose structures [48, 49], with temperatures of maximum degradation at $348{ }^{\circ} \mathrm{C}$ and $336{ }^{\circ} \mathrm{C}$ for the nonfunctionalised and in situ functionalised cotton textiles, respectively. According to information found in the literature, the thermal degradation of cellulose is the result of its depolymerisation and dehydration of volatile products, causing the formation of aliphatic char $[50,51]$. For temperatures between 400 and $700{ }^{\circ} \mathrm{C}$, this aliphatic char carbonises in aromatic char and further oxidises into $\mathrm{CO}$ and $\mathrm{CO}_{2}$ [50]. The percentages by weight of the residuals at $700{ }^{\circ} \mathrm{C}$ were found by thermogravimetric analysis to be 10.5 and 16.7 for the nonfunctionalised and in situ functionalised textiles, respectively. The greater residual

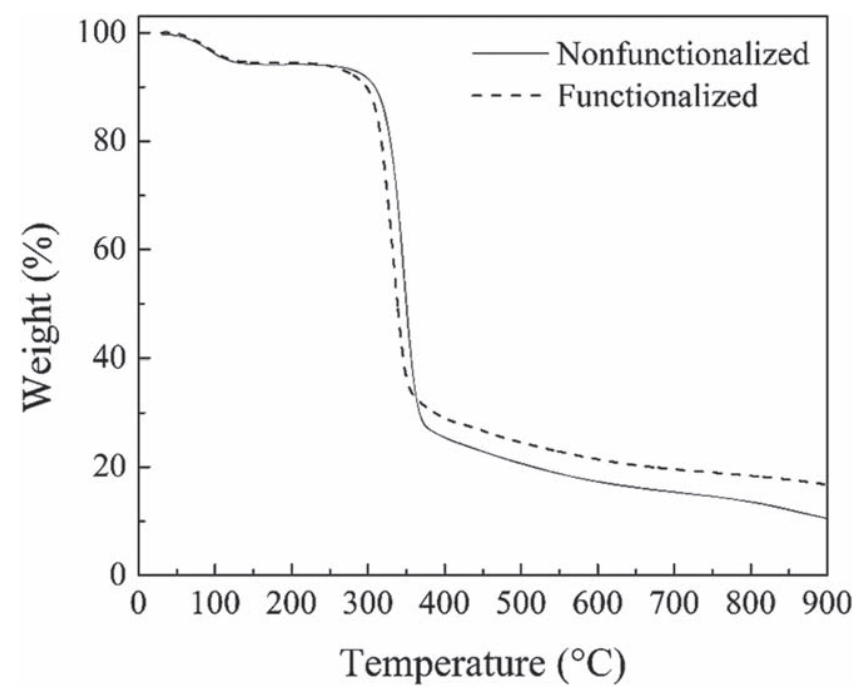

Figure 8. TGA curves of (a) nonfunctionalised and (b) in situ functionalised cotton textiles with $\mathrm{CuO}$ NPs prepared using $30 \%$ owf $\mathrm{Cu}\left(\mathrm{CH}_{3} \mathrm{COO}\right)_{2} \cdot \mathrm{H}_{2} \mathrm{O}$.

percentage of the functionalised textile using $30.0 \%$ owf copper acetate indicates that in addition to the presence of aromatic char, there is $\mathrm{CuO}$. Finally, considering that the nonfunctionalised textile residual is composed of only aromatic char and assuming that the aromatic char percentage is the same as that of the functionalised textile, $2.6499 \mathrm{mg}$ of $\mathrm{CuO}$ NPs was obtained, which represents approximately $6 \%$ of the total weight of the textile used in the functionalisation process.

The surface morphology of the nonfunctionalised cotton textiles and those in situ functionalised with $30.0 \%$ owf $\mathrm{Cu}\left(\mathrm{CH}_{3} \mathrm{COO}\right)_{2} \cdot \mathrm{H}_{2} \mathrm{O}$ were investigated by FESEM, as displayed in figure 9. Figure 9(a) shows that the nonfunctionalised textile is composed of clean cotton fibres without any particles on the surface; for the functionalised textile (figure 9(b)), the $\mathrm{CuO}$ NPs were deposited on the cotton surface and appeared as white particles scattered throughout the entire fibre. According to Zare Y, Rhee KY, and Hui D (2017), the agglomeration tendency of the nanoparticles is due to the strong attraction between the particles generated by their large surface area per unit volume [52], and as a result of this agglomeration, the nanoparticles acquire different shapes. For this reason, in the $200 \mathrm{k} \times$ magnified image (figure 9(c)), the white particles, seen in figure 9(b), are the result of the agglomeration of very small particles of different sizes and shapes.

In addition to these results and to determine the behaviour of functionalised fabrics when immersed in water, wash cycles were carried out. As shown figure 10(b), the textile sample functionalised with $30.0 \%$ owf $\mathrm{Cu}\left(\mathrm{CH}_{3} \mathrm{COO}\right)_{2} \cdot \mathrm{H}_{2} \mathrm{O}$, even after twenty washes, still presents randomly distributed $\mathrm{CuO}$ particles on the cotton fibre surface but the particles were less abundant in this textile sample than in the textile sample functionalised with the same concentration of copper acetate before washing (figure 10(a)).

To determine the laundering durability of in situ functionalised cotton textile using 0.8 and $30.0 \%$ owf 

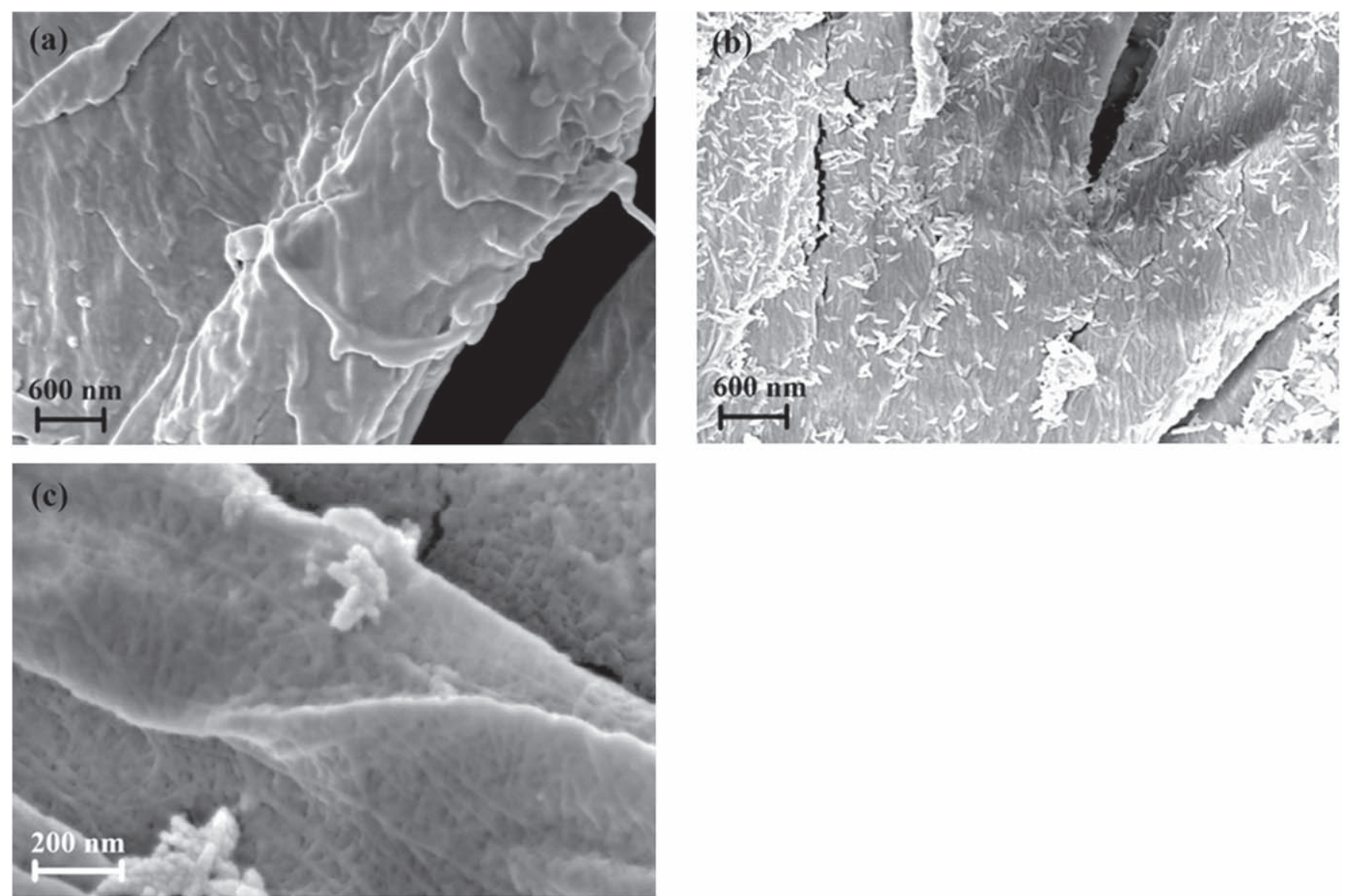

Figure 9. FESEM images of cotton textiles that were (a) nonfunctionalised and in situ functionalised with $\mathrm{CuO} \mathrm{NPs}$ using $30 \%$ owf $\mathrm{Cu}$ $\left(\mathrm{CH}_{3} \mathrm{COO}\right)_{2} \cdot \mathrm{H}_{2} \mathrm{O}$ at (b) $50,350 \times$ and (c) $200,000 \times$ magnification.
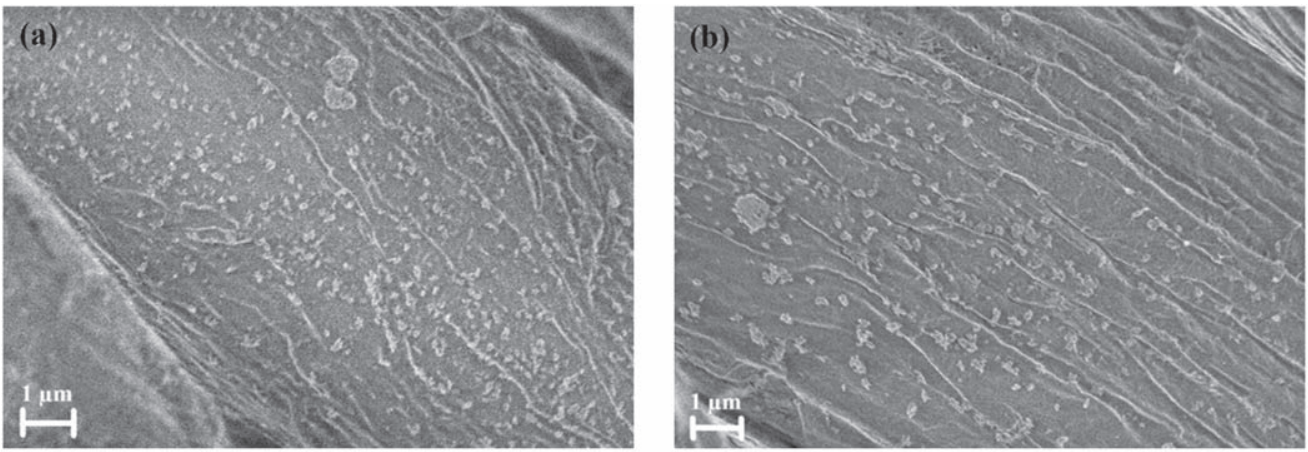

Figure 10. FESEM images of functionalised cotton textile with $30 \%$ owf $\mathrm{Cu}\left(\mathrm{CH}_{3} \mathrm{COO}\right)_{2} \cdot \mathrm{H}_{2} \mathrm{O}$ (a) before and (b) after 20 washes.

Table 1. Antibacterial activities of functionalised cotton textile against Escherichia coli before and after 20 washes.

\begin{tabular}{lccc}
\hline & & \multicolumn{2}{c}{$\begin{array}{c}\text { Bacteria } \\
\text { reduction }(\%)\end{array}$} \\
\cline { 3 - 4 } Samples & $\begin{array}{c}\mathrm{Cu}\left(\mathrm{CH}_{3} \mathrm{COO}\right)_{2} \cdot \mathrm{H}_{2} \mathrm{O} \\
(\% \text { owf })\end{array}$ & $\begin{array}{c}\text { Before } \\
\text { washing }\end{array}$ & $\begin{array}{c}\text { After 20 } \\
\text { washes }\end{array}$ \\
\hline Nonfunctionalised & - & 0 & 0 \\
Functionalised & 0.8 & 91.2 & 57.2 \\
& 30.0 & 99.10 & 98.20 \\
\hline
\end{tabular}

$\mathrm{Cu}\left(\mathrm{CH}_{3} \mathrm{COO}\right)_{2} \cdot \mathrm{H}_{2} \mathrm{O}$, twenty washing cycles were performed according to the ISO 105-C06:1994 standard (table 1). The results show that the antimicrobial activity of cotton textile functionalised with $\mathrm{CuO}$ NPs is reduced with washing cycles [8]; in our case, it was reduced by approximately $37 \%$ and $1 \%$ after 20 washes for $0.8 \%$ and $30.0 \%$ owf $\mathrm{Cu}\left(\mathrm{CH}_{3} \mathrm{COO}\right)_{2} \cdot \mathrm{H}_{2} \mathrm{O}$, respectively. Nevertheless, the washed functionalised textiles still exhibit antibacterial activity against the $E$. coli strain, with a percent bacterial reduction of more than $55 \%$ for the two concentrations of copper acetate mentioned above. The reduction in the antimicrobial capacity 


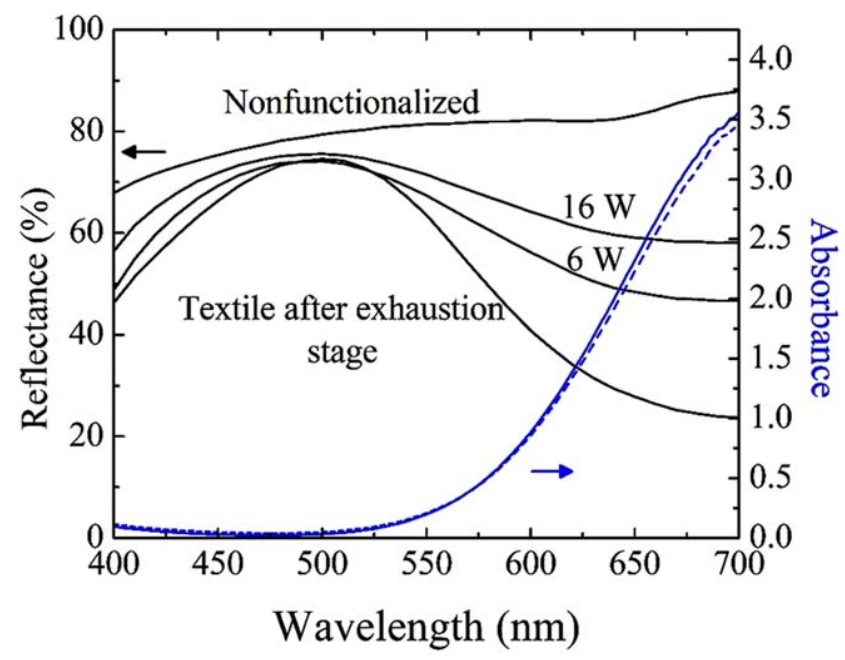

Figure 11. Reflectance (black lines) of nonfunctionalised textile and textile collected after the exhaustion stage with $30 \%$ owf $\mathrm{Cu}$ $\left(\mathrm{CH}_{3} \mathrm{COO}\right)_{2} \cdot \mathrm{H}_{2} \mathrm{O}$ and after 6 and 16 washes $(\mathrm{W})$, and absorbance (blue lines) of the aqueous solution of $\mathrm{Cu}\left(\mathrm{CH}_{3} \mathrm{COO}\right)_{2} \cdot \mathrm{H}_{2} \mathrm{O}$.

may be attributed to a loss of $\mathrm{CuO} \mathrm{NP}$ content on the textile surface due to friction between the stainless-steel balls and the textile sample during washing. This loss is corroborated in figure 10, that displays the FESEM images of functionalised cotton textile with $30 \%$ owf $\mathrm{Cu}\left(\mathrm{CH}_{3} \mathrm{COO}\right)_{2} \cdot \mathrm{H}_{2} \mathrm{O}$, before and after 20 washes. This reduction may also be due to $\mathrm{CuO}$ dissolution to form copper ions; these ions are released in the wash water [26, 36].

Figure 11 displays the reflectance as well as the absorbance measured in the wavelength range from 400 to $700 \mathrm{~nm}$. The reflectance of nonfunctionalised cotton textile shows values between $68.04 \%$ at $400 \mathrm{~nm}$ and $87.49 \%$ at $700 \mathrm{~nm}$. On the other side, the textile sample taken after the exhaustion stage with $30 \%$ owf $\mathrm{Cu}\left(\mathrm{CH}_{3} \mathrm{COO}\right)_{2} \cdot \mathrm{H}_{2} \mathrm{O}$ clearly presents a maximum reflectance of $74.39 \%$ at $494 \mathrm{~nm}$, which corresponds to a combination of green and blue shades [53], and a minimum of $23.56 \%$ at $700 \mathrm{~nm}$. It is important to point out that the minimum of the reflectance could be located at a higher wavelength, but the spectrophotometer only allows measurements in the analysed range. After 6 and 16 washing cycles $(W)$, the maximum reflectance increased slightly by $1 \%$ for the sample with $16 \mathrm{~W}$, while the minimum reflectance increased strongly to $46.65 \%$ and $58.28 \%$ for the sample after $6 \mathrm{~W}$ and $16 \mathrm{~W}$, respectively. The same figure displays the absorbance spectra for the solution used for the $30.0 \%$ owf $\mathrm{Cu}\left(\mathrm{CH}_{3} \mathrm{COO}\right)_{2} \cdot \mathrm{H}_{2} \mathrm{O}$ exhaustion and the solution after the exhaustion stage. These absorbance features exhibit the same performance between $400 \mathrm{~nm}$ and $600 \mathrm{~nm}$, but for longer wavelengths the absorbance from the solution used for the exhaustion increases more than that from the solution after the exhaustion stage. The increment is more noticeable at $700 \mathrm{~nm}$, where the solution used for exhaustion was 3.55 while the absorbance for the solution after exhaustion was 3.47. This effect is more likely a consequence of the small amount of copper complex retained in the textile during the exhaustion stage. The absorbance spectra of both solutions were ascribed to the hexaaquacopper (II) ion $\left[\mathrm{Cu}\left(\mathrm{H}_{2} \mathrm{O}\right)_{6}\right]^{2+}$

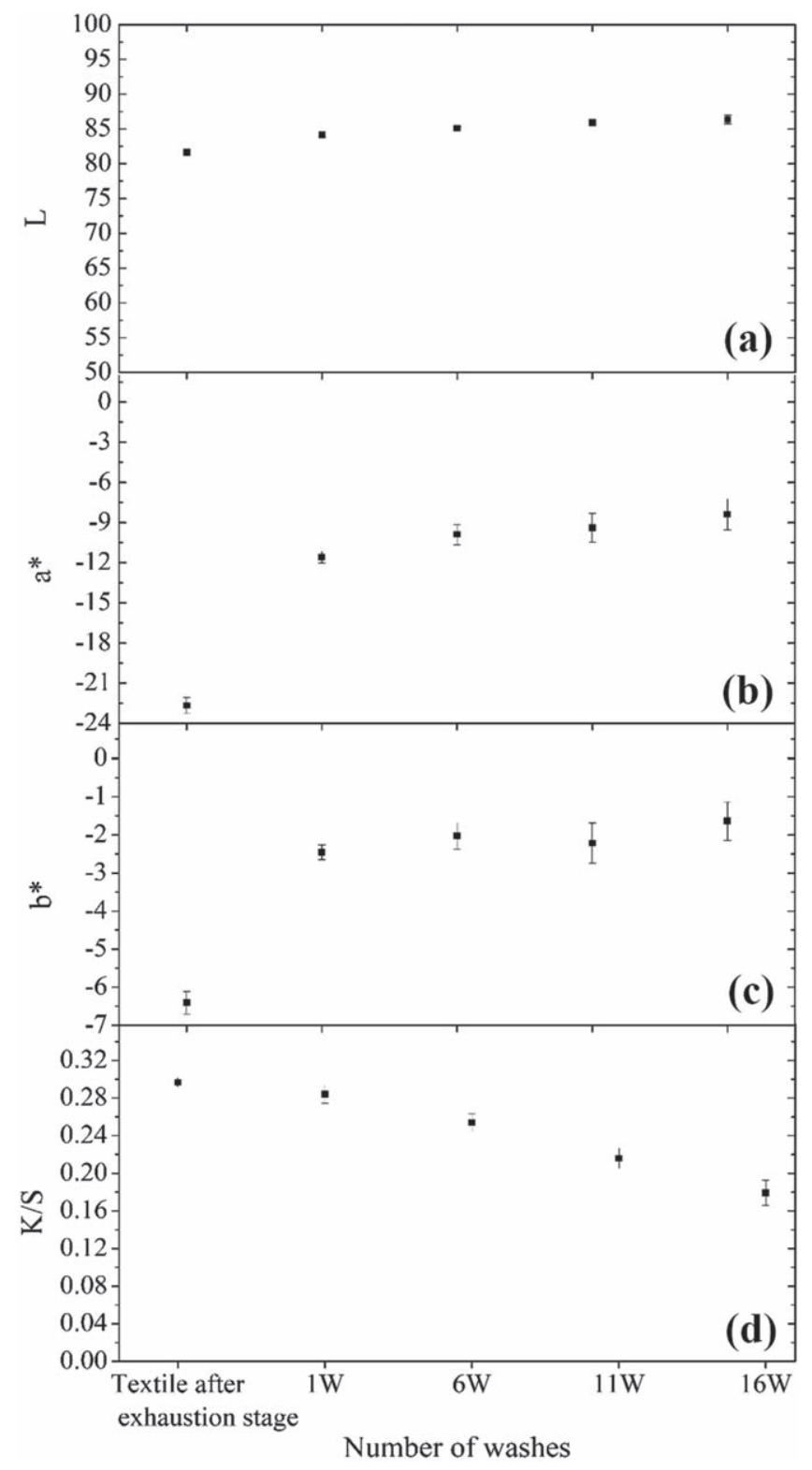

Figure 12. Colourimetric analysis of textile after $30 \%$ owf $\mathrm{Cu}$ $\left(\mathrm{CH}_{3} \mathrm{COO}\right)_{2} \cdot \mathrm{H}_{2} \mathrm{O}$ exhaustion stage and with $1,6,11$ and 16 washes (W): (a) $L$ (lightness), (b) $a *$ (red-green axis), (c) $b *$ (yellow-blue axis) and (d) colour strength $(K / S)$.

complex [54], which would mean that the adductors from acetate would have been displaced by the aqua ligands, since thermodynamically this process is favourable at room temperature $[55,56]$. After the exhaustion process, it was expected that the textile, as a substrate, will contain ion molecules of the $\left[\mathrm{Cu}\left(\mathrm{H}_{2} \mathrm{O}\right)_{6}\right]^{2+}$ complex, mainly concentrated on its surface [57]. Surprisingly, after the washing cycles, the complex was still clearly present and seen as a signal showing that the complex could replace some aqua ligands by the $-\mathrm{OH}$ groups from the fibre. This complex-fibre bonding could have become a seed for the $\mathrm{CuO}$ NP.

Figure 12 shows CIE $L * a * b *$ colour coordinates and colour strength $(K / S)$ values for the textile after the $30 \%$ owf $\mathrm{Cu}\left(\mathrm{CH}_{3} \mathrm{COO}\right)_{2} \cdot \mathrm{H}_{2} \mathrm{O}$ exhaustion stage and with $1 \mathrm{~W}, 6 \mathrm{~W}, 11 \mathrm{~W}$ and $16 \mathrm{~W}$. Figure 12(a) displays a slight increase in the 
lightness $(L *)$ of the textile after washing cycles, standing a value of $81.63 \%$ for the sample after the exhaustion stage, and $86.34 \%$ for the sample with $16 \mathrm{~W}$. Figures 12(b) and 12(c) give complementary information indicating that textiles had green-blue shades that decrease with $W$. This fact confirms the information discussed in figure 11. Finally, figure 12(d) displays that the values of $K / S$ decrease linearly for the analysed samples.

These results of bacterial growth inhibition, laundering durability and UV protection of functionalised cotton textiles with $\mathrm{CuO}$ NPs obtained by the conventional dyeing method (exhaust dyeing) are favourable and encouraging for applications in sanitary products from public places exposed to constant bacterial contamination, such as hospitals. Products such as bed sheets, blankets, towels, personal clothing, patient apparel, uniforms, gowns, and drapes for surgical procedures $[58,59]$ are ideal candidates for these functionalised cotton textiles to prevent and reduce healthcare-associated infections.

\section{Conclusions}

The in situ growth of $\mathrm{CuO}$ NPs on cotton textiles was carried out by the exhaust dyeing method. The $\mathrm{CuO}$ NPs gave the textile a grayish-brown shade of low chromaticity that varies in lightness. The lightness values of the functionalised textiles decreased with increasing copper acetate percentage in the exhaustion stage, indicating a gradual increase in the $\mathrm{CuO}$ NP content on the textiles. This result was reinforced by the colour strength values. That is, a high $\mathrm{K} / \mathrm{S}$ value was associated with a large number of particles on the textiles. The asprepared functionalised cotton textiles using as low as $0.4 \%$ owf $\mathrm{Cu}\left(\mathrm{CH}_{3} \mathrm{COO}\right)_{2} \cdot \mathrm{H}_{2} \mathrm{O}$ displayed an inhibition growth of Escherichia coli bacteria greater than $90 \%$ and a UPF higher than 22. After 20 washes, functionalised cotton textiles using $0.8 \%$ and $30 \%$ owf $\mathrm{Cu}\left(\mathrm{CH}_{3} \mathrm{COO}\right)_{2} \cdot \mathrm{H}_{2} \mathrm{O}$ presented the decrease in bacteria reduction of $38 \%$ and $1 \%$, respectively, confirming the deanchoring of $\mathrm{CuO}$ NPs from the textile. The $\mathrm{CuO}$ NPs were agglomerated on the surface of cotton fibre, and their structure was confirmed by XRD to correspond to that of $\mathrm{CuO}$. The $\mathrm{CuO}$ NP content on the functionalised textile prepared using 30\% owf copper acetate represented $6 \%$ of the total weight of the same textile. A strong interaction of the hexaaquacopper (II) ion $\left[\mathrm{Cu}\left(\mathrm{H}_{2} \mathrm{O}\right)_{6}\right]^{+2}$ complex with the fibre was established during the exhaustion stage, which suggests that $\mathrm{H}_{2} \mathrm{O}$ ligands could be replaced by $-\mathrm{OH}$ groups from the fibre. One copper complex strongly attached at cotton fibre could serve as a seed for the in situ $\mathrm{CuO}$ NP growth. Finally, the proposed functionalisation process can be an economic and innovative alternative for use in the textile industry.

\section{Acknowledgments}

This work was supported by the National Innovation Program for Competitiveness and Productivity, the Ministry of Production of Peru (Contract 368 PNICP-PIAP) and the Vice-Presidency for Research of the National University of Engineering (VRI-UNI). L.E.R. thanks FONDECYT for a doctoral scholarship within the agreement No. 05-2018FONDECYT/BM.

\section{References}

[1] Barabadi H, Tajani B, Moradi M, Damavandi Kamali K, Meena R, Honary S, Mahjoub M A and Saravanan M 2019 J. Cluster Sci. 30843

[2] Boomi P, Poorani G P, Palanisamy S, Selvam S, Ramanathan G, Ravikumar S, Barabadi H, Prabu H G, Jeyakanthan J and Saravanan M 2019 J. Cluster Sci. 30715

[3] Colonia R C, Solís J L and Gómez M M 2014 Adv. Nat. Sci.: Nanosci. Nanotechnol. 5015008

[4] Doran J and Ryan G 2019 Technol. Soc. 59101183

[5] Mangematin V and Walsh S 2012 Technovation 32157

[6] Mangala J and Bapan A 2019 Comprehensive Nanoscience and Nanotechnology (New Delhi: Elsevier)

[7] Yetisen A K, Qu H, Manbachi A, Butt H, Dokmeci M R, Hinestroza J P, Skorobogatiy M, Khademhosseini A and Yun S H 2016 ACS Nano 103042

[8] El-Nahhal I M, Elmanama A A, Amara N, Qodih F S, Selmane M and Chehimi M M 2018 Mater. Chem. Phys. 215221

[9] Hassabo A G, El-Naggar M E, Mohamed A L and Hebeish A A 2019 Carbohydr. Polym. 210144

[10] Mazzon G, Zahid M, Heredia-Guerrero J A, Balliana E, Zendri E, Athanassiou A and Bayer I S 2019 Appl. Surf. Sci. 490331

[11] Montazer M and Maali Amiri M 2014 J. Phys. Chem. B 1181453

[12] Román L E, Huachani J, Uribe C, Solís J L, Gómez M M, Costa S and Costa S 2019 Appl. Surf. Sci. 469204

[13] Hoseinzadeh E, Makhdoumi P, Taha P, Hossini H, Stelling J, Kamal M A and Ashraf G M 2017 Curr. Drug Metab. 18120

[14] Ranjan S and Ramalingam C 2016 Environ. Chem. Lett. 14487

[15] Bajpai S K, Jadaun M and Tiwari S 2016 Carbohydr. Polym. 15360

[16] Cano A P, Gillado A V, Montecillo A D and Herrera M U 2018 Mater. Chem. Phys. 207147

[17] Amiri M, Etemadifar Z, Daneshkazemi A and Nateghi M 2017 J. Dent. Biomater. 4347

[18] Altavilla C and Ciliberto E 2011 Inorganic Nanoparticles: Synthesis, Applications, and Perspectives (Florida: Taylor \& Francis Group)

[19] Marcus E-L, Yosef H, Borkow G, Caine Y, Sasson A and Moses A E 2017 Am. J. Infect. Control 45401

[20] Ghorbi E, Namavar M, Rashedi V, Farhadinejad S, Pilban Jahromi S and Zareian M 2019 Colloids Surf. A. 580 123732

[21] Nabila M I and Kannabiran K 2018 Biocatal. Agric. Biotechnol. 1556

[22] Nabil B, Ahmida E A, Christine C, Julien V and Abdelkrim A 2018 Chem. Eng. J. 351328

[23] Das D, Nath B C, Phukon P and Dolui S K 2013 Colloids Surf. B. 101430

[24] Rezaie A B, Montazer M and Rad M M 2017 J. Photochem. Photobiol. B 176100

[25] Gouda M, Aljaafari A, Al-Fayz Y and Boraie W E 2015 J. Nanomater. 2015586904

[26] Thampi V V A, Thanka Rajan S, Anupriya K and Subramanian B 2015 J. Nanopart. Res. 1757 
[27] Petrucci R H, Herring F G, Madura J D and Bissonnette C 2011 Química general (Madrid: Pearson)

[28] Zhu J, Bi H, Wang Y, Wang X, Yang X and Lu L 2007 Mater. Lett. 615236

[29] Sonia S, Jayram N D, Suresh Kumar P, Mangalaraj D, Ponpandian N and Viswanathan C 2014 Superlattices Microstruct. 661

[30] Yoosefi A, Wang R and Xu R 2015 Chem. Eng. J. 262 999

[31] Schindler W D and Hauser P J 2004 Chemical finishing of textiles (Cambridge: Woodhead Publishing)

[32] Vigo T L 1994 Textile Processing and Properties: Preparation, Dyeing, Finishing and performance (New Orleans: Elsevier)

[33] Standards United States 2015 Transmittance or Blocking of Erythemally Weighted Ultraviolet Radiation Through Fabrics (AATCC 183:2014)

[34] Standards Australia 1996 Sun Protective Clothing - Evaluation and Classification (AS/NZS 4399:1996)

[35] Standards United States 1994 Textiles - Tests for Colour Fastness Part C06:Colour Fastness to Domestic and Commercial Laundering (ISO 105-C06:1994)

[36] Rezaie A B, Montazer M and Rad M M 2018 J. Cleaner Prod. 204425

[37] Broadbent A D 2001 Basic Principles of Textile Coloration (Canada: Society of Dyers and Colourists)

[38] Metwally M A, Abdel-Galil E, Metwally A and Amer F A 2012 Dyes Pigm. 92902

[39] Román L E, Castro F, Maúrtua D, Condori C, Vivas D, Bianchi A E, Paraguay-Delgado F, Solis J L and Gómez M M 2017 Rev. Colomb. Quim. 4628

[40] Palza H 2015 Int. J. Mol. Sci. 162099
[41] Rezaie A B, Montazer M and Rad M M 2017 J. Cleaner Prod. 166221

[42] Tamayo L, Azocar M, Kogan M, Riveros A and Paez M 2016 Mater. Sci. Eng. C. 691391

[43] Applerot G, Lellouche J, Lipovsky A, Nitzan Y, Lubart R, Gedanken A and Banin E 2012 Small 83326

[44] Almutawa F and Buabbas H 2014 Dermatol. Clin. 32439

[45] Kan C-W and Au C-H 2015 PLoS One. 10 e0133416

[46] Majumdar A, Das A and Hatua P 2015 Fibers Polym. 161163

[47] Markovic D, Deeks C, Nunney T, Radovanovic Z, Radoicic M, Saponjic Z and Radetic M 2018 Carbohydr. Polym. 200173

[48] Agathian K, Kannammal L, Meenarathi B, Kailash S and Anbarasan R 2018 Int. J. Biol. Macromol. 1071102

[49] Shankar S, Oun A A and Rhim J W 2018 Int. J. Biol. Macromol. 10717

[50] Fang F, Zhang X, Meng Y, Gu Z, Bao C, Ding X, Li S, Chen X and Tian X 2015 Surf. Coat. Technol. 2629

[51] Carosio F, Fontaine G, Alongi J and Bourbigot S 2015 ACS Appl. Mater. Interfaces 712158

[52] Zare Y, Rhee K Y and Hui D 2017 Composites Part B. 12241

[53] Zhang B, Zhu J, Shi P, Wang F, Wang J and Ren Z 2019 J. Eur. Ceram. Soc. 391925

[54] Cotton F A and Wilkinson G 1972 Advanced Inorganic Chemistry (New York: Interscience Publishers)

[55] Cheng A T A and Howald R A 1975 Inorg. Chem. 14546

[56] Sandved K 1927 J. Chem. Soc. 02967

[57] O'Connell D W, Birkinshaw C and O'Dwyer T F 2006 J. Appl. Polym. Sci. 992888

[58] Perelshtein I, Lipovsky A, Perkas N, Tzanov T, Arguirova M, Leseva M and Gedanken A 2015 Ultrason. Sonochem. 2582

[59] Bartels V T 2011 Handbook of Medical Textiles (Cambridge: Woodhead Publishing) 